\title{
TPD52L1 wt Allele
}

National Cancer Institute

\section{Source}

National Cancer Institute. TPD52L1 wt Allele. NCI Thesaurus. Code C52141.

Human TPD52L1 wild-type allele is located within 6q22-q23 and is approximately $111 \mathrm{~kb}$ in length. This allele, which encodes tumor protein D53, may play a role in the regulation of calcium signaling, cellular proliferation and apoptosis. 